\title{
Land use/land cover change dynamics and drivers in a low-grade marginal coffee growing region of Veracruz, Mexico
}

\author{
Edward A. Ellis • Kenneth A. Baerenklau • \\ Raymundo Marcos-Martínez • Edgar Chávez
}

Received: 13 July 2009/ Accepted: 16 July 2010/Published online: 30 July 2010

(C) The Author(s) 2010. This article is published with open access at Springerlink.com

\begin{abstract}
In the state of Veracruz, Mexico, lowland and marginal coffee growing regions have been particularly vulnerable since the 1989 coffee crisis. Government programs have promoted production diversification as a strategy to improve local incomes and conserve environmentally beneficial shade-tree coffee agroforests. We present results on land use/ land cover dynamics in the municipality of Zozocolco de Hidalgo from 1973 to 2006. The municipality is recognized for its indigenous population and poverty, and currently, diversification efforts are being implemented. Our study combines remote sensing and GIS analyses, binary logistic regression and econometric modeling, as well as socioeconomic surveys to evaluate land use/land cover change (LULCC) dynamics and explore potential environmental and socioeconomic drivers. Results show that tree cover and coffee agroforests had largely been conserved during the first decade after the coffee crisis. But, recent trends indicate loss of tree cover in coffee
\end{abstract}

\section{E. A. Ellis ( $\bowtie)$}

Centro de Investigaciones Tropicales, Universidad Veracruzana, Interior de la Ex Hacienda Lucas Martin, Calle Araucarias s/n Col. 21 de Marzo, C.P. 91010

Xalapa, Veracruz, Mexico

e-mail: ellis_eddie@yahoo.com; eellis@uv.mx

K. A. Baerenklau · R. Marcos-Martínez · E. Chávez Department of Environmental Sciences, University of California, 2460D Geology Building, Riverside, CA 92521, USA agroforests and their conversion mostly to pasture. Land use/land cover drivers are largely explained by spatially explicit environmental variables such as slope and elevation. Relevant socioeconomic variables such as distance to markets and land use profitability were not significantly related to land use changes in Zozocolco. Surveys revealed that many households had converted coffee agroforests to pasture or agriculture in the past decade and others intended on renting or selling their agroforest plots, mostly for conversion to pasture. Diversification programs may not be sufficient to stem deforestation in lowland and marginal coffee growing regions. Moreover, information about locally varying socioeconomic and cultural contexts needs to be strongly considered in order to formulate effective strategies.

Keywords Land use/land cover change · Coffee agroforests - Spatial modeling . Econometric modeling · Veracruz · Mexico

\section{Introduction}

Land use/land cover change (LULCC) is recognized as a key component of environmental change at global, regional and local scales. Changes in land use and land cover have implications for global warming, loss of biodiversity, degradation of soils, watershed 
hydrology and even human well-being (Lambin et al. 2001; Geist and Lambin 2001, 2002). However, the processes and factors associated with LULCC are very complex, resulting from the interaction of human-environment systems which are influenced by an array of environmental, socioeconomic, policy and institutional factors which can be regarded as drivers (Overmars and Verburg 2005, 2006; Rindfuss et al. 2004; Geist and Lambin 2001, 2002). In that respect, LULCC research has been pivotal in exploring the dynamics and socioeconomic and biophysical drivers associated with LULCC which can support conservation and development planning and policy (Roy Chowdhury and Schneider 2004; Munroe et al. 2004; Verburg et al. 2004).

In Mexico, LULCC is an important issue due the extreme deforestation process which has been occurring, particularly during the past four decades. Ranking fourth in the world, deforestation is clearly a major environmental problem in Mexico (FAO 2006). The state of Veracruz is among the worst cases of deforestation in the country, being second in the nation with presently over $75 \%$ of its territory deforested (SEMARNAT 2005). According to Ellis et al. (2010), only 26\% of the state's natural vegetation cover remains, including secondary vegetation, and only $8.6 \%$ of this vegetation can be considered as well conserved. For that matter, secondary forests and agroforests comprise an important component of tree cover in Veracruz. The threat of deforestation in many regions of Mexico, including Veracruz, not only applies to conserved or secondary forest cover, but also to the loss of agroforests.

Agroforests are present throughout southeast Mexico and used by many communities for the production of coffee, cacao, pepper, bananas and other commodities. In Mexico, almost $90 \%$ of its coffee is produced in mixed systems with shade trees and $40 \%$ in "traditional," "rustic" or "bajo monte" systems which have relatively dense and diverse tree cover (Ávalos-Sartorio and Blackman 2009; Gordon et al. 2007). These shade coffee agroforests in particular are often regarded as surrogate forests due to their similar ecological functions and services (ÁvalosSartorio and Blackman 2009; Gordon et al. 2007; Somarriba et al. 2004). For example, shade coffee agroecosystems have been reported to support a significant level of biodiversity comparable to natural forests (Gordon et al. 2007; Somarriba et al. 2004). In fact, in Mexico, all of its main coffee-growing regions are also designated as biodiversity "hotspots" (Ávalos-Sartorio and Blackman 2009), and the same situation is reported in the state of Veracruz (Ellis et al. 2010). Due to the presence of tree cover, these agroforestry systems are potentially more conducive to carbon sequestration and soil and water conservation than land use systems without trees such as maize cropping and pasture for cattle rearing (Blackman et al. 2008a; Pearce and Mourato 2004). Moreover, these agroforests can be integral landscape components that function as corridors between forest fragments and reduce edge effects of neighboring forests (Blackman et al. 2008a; Schroth et al. 2004). In some cases, these tree-based agroecosystems may reduce pressures of deforestation (Angelsen and Kaimowitz 2004) and at least maintain tree cover in agroforest landscapes. However, their conversion to non-agroforestry agricultural systems may occur if economic and institutional conditions are unfavorable, resembling deforestation processes with similar negative environmental impacts (Angelsen and Kaimowitz 2004).

Besides their environmental benefits, coffee production from these agroforests is an important economic resource at national, regional and local scales, including in the state of Veracruz (Blackman et al. 2008a; Mestries Benquet 2003; Vázquez García 2001). Mexico produces $3.5 \%$ of the world's coffee and exports $2 \%$ of total world exports, which makes it the third largest coffee producer in Latin America and tenth worldwide (Romero Leon et al. 2006; BANCOMEXT 2005; ICO 2005). At a national scale, the state of Veracruz stands out as the second most important coffee producer in Mexico (Gordon et al. 2007; COVECA 2002). Coffee production in Mexico represents a major source of income for up to 481,000 households cultivating 665,000 ha and providing up to one million jobs annually (ÁvalosSartorio and Blackman 2009). Moreover, coffee agroforests in Mexico often provide additional sources of income and subsistence products such as black pepper, fruits, timber and fuelwood. These benefits are important, considering the majority of coffee farmers in Mexico own parcels smaller than 2 ha located within Mexico's poorest and most socioeconomically marginalized regions (ÁvalosSartorio and Blackman 2009). 
Coffee prices and its production in Mexico, however, have fluctuated significantly in the past decades (ICO 2009). Since the early 1970s and during the 1980s, while coffee production was economically favorable, the Mexican government began to promote and provide technical support and subsidies for its improvement, expansion, processing and commercialization via the institution INMECAFE (Mexican Institute of Coffee) (Romero Leon et al. 2006; COVECA 2002). In fact, during the 1980 s, when prices were high, coffee became Mexico's most important export crop (Tucker et al. 2009; Romero Leon et al. 2006; COVECA 2002). Between 1975 and 1985, coffee cultivation expanded by $50 \%$ in Mexico and by $29 \%$ in the state of Veracruz (Tucker et al. 2009). Unfortunately, after 1989, due to extreme competition from other countries with favorable coffee growing environments entering into the global coffee market (e.g., Vietnam) and causing a global oversupply, the coffee price plummeted by $50 \%$ (Ponette-González 2007; Romero Leon et al. 2006; COVECA 2002). Coupled with the worldwide economic coffee crisis, neoliberal economic reforms that began to be implemented during the 1990s resulted in the elimination of INMECAFE, and with it, the subsidies for coffee production, processing and commercialization it provided (Romero Leon et al. 2006; Vázquez García 2001). As a response to the crisis, donor agencies and policy-makers typically reacted by promoting quality and efficiency in areas most suited for coffee growing, while promoting conversion to other crops in areas less suitable for coffee production (Tucker et al. 2009). Consequently, the coffee crisis has brought about significant changes to the coffee sector in Mexico, dramatically affecting coffee growing regions as well as household economies throughout the country (Romero Leon et al. 2006; Vázquez García 2001).

The economic impacts of the coffee crisis in Mexico have been severe, reducing production by $21 \%$, exports by $51 \%$ and revenue by $80 \%$ between 1990 and 2004 (Ávalos-Sartorio and Blackman 2009). In some years, coffee farmers could not receive prices that exceeded average production costs (Ávalos-Sartorio and Blackman 2009). Particularly, between 1999 and 2003, international coffee prices fell to historical lows (Tucker et al. 2009). Nevertheless, although unfavorable coffee prices continued well into this decade, those producers who could supply high-quality coffee sold at premium prices to satisfy U.S. and European demand for specialty coffee have been able to cope with the crisis (Gordon et al. 2007; Romero Leon et al. 2006; COVECA 2002). High quality coffee in subtropical regions such as Veracruz is produced in elevations around $1000 \mathrm{~m}$. On the other hand, marginal coffee growing regions in the state producing low-grade coffee are present in elevations below $1000 \mathrm{~m}$. In the state of Veracruz, low-grade coffee-growing regions in lower elevations have been the most vulnerable and have undergone the most severe socioeconomic impacts since the 1989 coffee crisis (Romero Leon et al. 2006; COVECA 2002).

Outcomes of the crisis in coffee growing regions of Mexico, range from the abandonment of coffee plantations, conversion of coffee parcels to other agricultural uses, migration, renting or selling of land, and dependence on off-farm labor for income (Ávalos-Sartorio and Blackman 2009; Blackman et al. 2007; Romero Leon et al. 2006; Mestries Benquet 2003; Vázquez García 2001). It has been claimed that up to 300,000 coffee growers in Mexico have abandoned their farms as a result of the coffee price crash (Gordon et al. 2007). All of these outcomes can have different impacts on LULCC dynamics in coffee growing regions, however, few studies have looked at these impacts in Mexico, specifically in the most susceptible lowland areas producing low-grade coffee.

In a high altitude coffee-growing region of centraleastern Veracruz, recognized for its high quality specialty coffee, one LULCC study showed a slight increase in areas of mixed agroforestry systems with shade-grown coffee from 1990 to 2003 (MuñozVillers and López-Blanco 2008). In contrast, coffee plantations cultivated without shade were converted to other uses such as sugar cane and pasture (MuñozVillers and López-Blanco 2008). Another study in the same region of central Veracruz reports only a slight decrease in all coffee plantations from 1973 to 1990 and from 1990 to 2003 (Martínez et al. 2009). These trends in central-eastern Veracruz are also confirmed through interviews that were conducted in 2003, indicating that only a small proportion of farmers were making land use changes, specifically farmers in lower altitudes who were converting coffee plantations to sugar cane (Tucker et al. 2009). Gordon et al. (2007) 
also indicate that sun coffee plantations were mostly affected in this region due to their greater loss in net revenue from falling prices compared to shade-grown coffee agroforests.

Blackman et al. (2008a) report that in a coffee growing region in the state of Oaxaca, Mexico, ranging from 400 to $1600 \mathrm{~m}$, land cover modeling shows that coffee plots closer to large cities with coffee markets were being conserved, and that conservation of coffee parcels was also associated with membership in marketing cooperatives, farm size and soil type. On the other hand, their results show that conversion of coffee plots, in this coffee growing region of Mexico, was more likely to occur in lower elevations and close to smaller towns without coffee markets (Blackman et al. 2008a). For this same region, Ávalos-Sartorio and Blackman (2009) corroborate that coffee farms associated with deforestation or loss of tree cover are those smaller in size, located in lower elevations and with communal land tenure. However, a LULCC study in El Salvador reports contrasting results of $13 \%$ of the country's coffee growing areas (between 600 and $1200 \mathrm{~m}$ in elevation) being cleared between 1990 and 2000 mostly in middle and high altitudes (Blackman et al. 2007). Moreover, Blackman et al. (2007) also claim that loss of tree cover in El Salvador's shade coffee regions is not only associated with falling coffee prices but also with decreasing on-farm investment and yields, debt, poverty, urbanization, migration and weak land use regulation.

Research involving LULCC in coffee growing regions demonstrates the complexity and differences of LULCC dynamics that can occur in each particular region. In the state of Veracruz, such research focusing on marginal lowland areas producing lowgrade coffee is sorely needed. These studies are essential since currently the state government and international funding agencies are promoting agricultural diversification projects targeting lowland areas producing low-grade coffee, specifically in poor and marginalized areas below $600 \mathrm{~m}$ in elevation (Romero Leon et al. 2006; COVECA 2002). Diversification of coffee plantations with alternative products, such as ornamentals, timber, papaya, guava and vanilla is among the main strategy being implemented in lowland marginal coffee regions in Veracruz in order improve local and household economies, while at the same time prevent the loss of shade-grown coffee agroforests (Romero Leon et al. 2006; COVECA 2002). A major project, funded by Common Fund for Commodities of the United Nations, Diversificación Productiva de Cafetales de Baja Altitud (DIPROCAFE) has been undertaking such initiatives in two municipalities in Veracruz (Zozocolco de Hidalgo and Atzalan) producing lowgrade coffee within altitudes of $300-800 \mathrm{~m}$. Yet, these strategies are being implemented without assessments on LULCC to evaluate impacts on land cover from falling coffee prices as well as monitor and gauge their success in preventing loss of tree cover through the conversion of agroforests.

In this paper, we present results on land use/land cover dynamics in the municipality of Zozocolco de Hidalgo between the periods of 1973 and 2006, emphasizing on tree cover within and outside of coffee agroforest regions. The municipality is a lowland and low-grade coffee producing region in the state of Veracruz recognized for its poverty and socioeconomic marginalization, and in which coffee diversification efforts have been implemented with farmers. Our study combines remote sensing and geographical information systems (GIS) analyses, binary logistic regression and econometric modeling, as well as socioeconomic surveys to evaluate LULCC dynamics in the municipality and explore the potential environmental and socioeconomic factors or drivers affecting changes in the landscape, mainly loss of tree cover. Spatially-explicit statistical models are used to evaluate different variables associated with LULCC, such as distance to roads, markets, and streams, slope, elevation, population, profit from land uses and others. Based on the results of this study, we discuss the observed dynamics of land use and tree cover in the municipality and their associated drivers, considering the potential impacts of the coffee crisis. Moreover, implications for promoting sustainable land use and agricultural production in similar lowland coffee growing regions of Mexico are discussed.

\section{Study area}

Zozocolco de Hidalgo is a small municipality in the state of Veracruz of approximately 7000 ha and located on the border with the state of Puebla $\left(20^{\circ} 08^{\prime} 23^{\prime \prime} \mathrm{N}\right.$ latitude and $97^{\circ} 34^{\prime} 32^{\prime \prime} \mathrm{W}$ longitude) 
(Fig. 1). The municipality lies within the Totonocapan region of Mexico, which ranges from the mountainous region of the Sierra Madre Oriental in the state of Puebla to the coastal plains in central and northern Veracruz (Del Angel-Pérez and Mendoza 2004). Population of the municipality, according to the 2000 national census, is 12,607 , with a population density of $180 / \mathrm{km}^{2}$ (del Amo et al. 2008). The majority of the population of Zozocolco de Hidalgo is indigenous, belonging to the totonaca culture, and its communities are categorized as having high marginalization indices by national standards, in other words, with extreme poverty levels and lacking proper transportation infrastructure and services such as electricity, clinics, potable water and primary schools (CONAPO 2009; King 2007; INEGI 2008).
Zozocolco de Hidalgo has a hilly topography ranging in elevation between 100 and $700 \mathrm{~m}$ above sea level (del Amo et al. 2008). Climate of the municipality is categorized, according to the Koppen system modified by García (1988), as A(f), warm and subhumid with a mean annual temperature of $22^{\circ} \mathrm{C}$ (ranging from 7 to $42^{\circ} \mathrm{C}$ ) and annual mean precipitation of $2258 \mathrm{~mm}$ (del Amo et al. 2008). Around $54 \%$ of the annual precipitation falls in the rainy season between the months of June and September, while a marked dry season may last 4-6 months, usually between October and March (García 1988). Soils in the municipality are for the most part lithosols (70\%), poorly developed and superficial soils with a depth of less than $10 \mathrm{~cm}$ containing substantial gravel and rocks characteristic of the hilly

Fig. 1 Location of study area

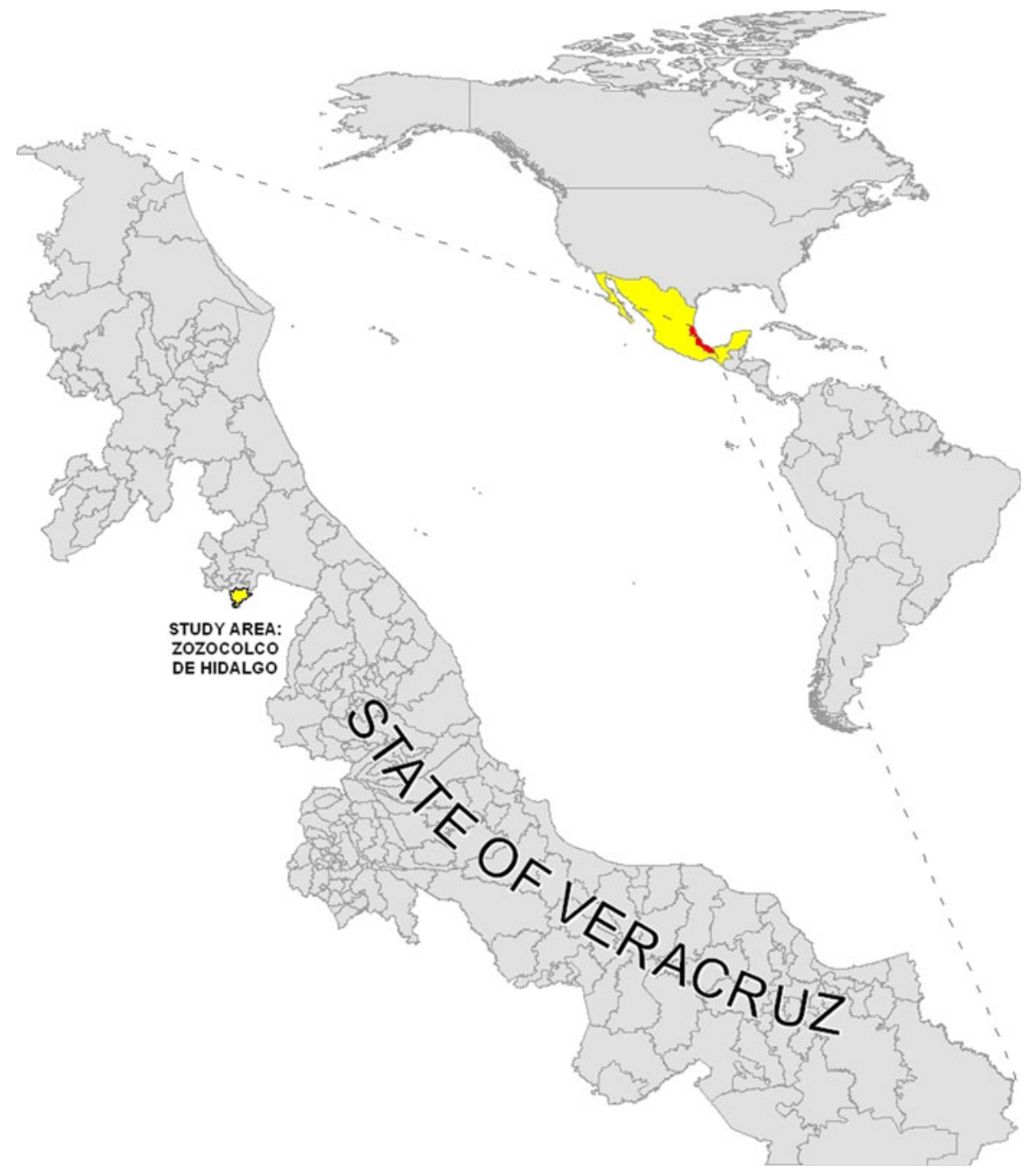


terrain in the region (Del Amo et al. 2008). These soils are characteristic of having agricultural management difficulties, particularly for tilling, and are also highly susceptible to erosion. However, maize, coffee, pepper and vanilla have been historically and are still currently cultivated (del Amo et al. 2008). Natural vegetation in the region consists of mediumstatured tropical evergreen forests (Del Angel-Pérez and Mendoza 2004). However, very little conserved natural forest remains in the municipality, located mostly on steep slopes, near river banks and on hill tops.

\section{Landscape use and history}

The landscape of the municipality is characterized as a mosaic of natural forests, secondary or fallow forests, shade-grown coffee agroforests, pasture and agriculture. It has been molded for centuries by anthropogenic agricultural, agroforestry and cattle raising activities (del Amo et al. 2008). Agricultural activities consist of cultivation of maize mostly for subsistence purposes. The crop is produced twice a year on small parcels ranging from 0.5 to 3 ha. Unlike more traditional maize cultivation systems, herbicides and fertilizers are applied and parcels are typically not left to fallow. In Zozocolco de Hidalgo, most household do not own their maize fields. In fact, although it is reported that $90-98 \%$ of the households in the municipality cultivate maize, up to $70 \%$ rent land for maize production (del Amo et al. 2008).

Cattle husbandry is also a prominent activity in Zozocolco de Hidalgo. While considerable areas in the municipality are under pasture, with 2900 ha reported in 1999, there are only 90 cattle producers in the entire municipality with approximately 1,000 heads of cattle. Pasture areas managed by these producers range from 8 to 400 ha. Of these producers, 11 of them are not residents of the municipality and own around $60 \%$ of total pasture areas. Pastures are often established in areas that were once cultivated but no longer are productive due to soil infertility and the presence of pests. Cattle are raised in a free ranging system and for the purpose of fattening and reproduction only (del Amo et al. 2008).

Agroforestry practices are related primarily to coffee production under shade trees in which pepper trees and fruit trees are also often included. There are around 500 coffee producers in the municipality with coffee agroforest parcels ranging from 0.5 to 2 ha. Black pepper began to be produced in the 1980s and gradually gained importance as an additional source of income since the 1990s after the coffee crisis. Still, coffee production has been paramount to the economy of Zozocolco de Hidalgo for over 50 decades. Consequently, municipal and state authorities are extremely concerned about the decline in coffee production since the 1989 crisis, and warn that some of these agroforests are being converted to other agricultural land uses.

During the colonial period (1535-1821), the region where Zozocolco de Hidalgo is located was inhabited by indigenous communities practicing subsistence agriculture and its main economic importance was for the production of vanilla (Ramírez Melgarejo 2002; Blanco 1987). Land tenure during this period consisted mostly of communal land use rights for indigenous communities and some private ownership of land for vanilla production. Under this land tenure regime, forest cover was maintained in the landscape through rotations of indigenous slash and burn agricultural systems and vanilla production, which is usually established and managed in fallow forest (del Amo et al. 2008). However, in the nineteenth century, the Mexican government imposed a system of private ownership, greatly reducing indigenous communal property through a process of parcelization and privatization of these lands which benefited outsiders rather than local indigenous populations.

Even though Mexico underwent a period of agrarian reform in the twentieth century (1920-1970), during which time government lands and large private landholdings were redistributed as communal lands called ejidos, these agrarian reforms did not make a significant impact in the Totonocapan region. A 1970 census of the region revealed that $75 \%$ of the land was under private ownership and only $25 \%$ had been redistributed as ejidos (del Amo et al. 2008; Ramírez Melgarejo 2002; Velásquez 1995). In Zozocolco de Hidalgo, ejido lands were designated to only two communities which totaled only a small portion (5\%) of the municipality (del Amo et al. 2008; Ramírez Melgarejo 2002). Finally, as a result of the agrarian counter-reform in 1992 which allowed the privatization and parcelization of ejido land, these particular ejidos became parcelized with each ejido member owning an average of 3-4 ha (del Amo et al. 2008). 
Transitions in land tenure towards parcelized private ownership impacted the landscape by reducing the availability of communal lands for indigenous traditional shifting agriculture as well as forested lands used to obtain a variety of products for subsistence purposes.

Since the nineteenth century and well into the twentieth century, agricultural production of coffee dominated the region of Zozocolco de Hidalgo. Vanilla also remained a very important economic crop, experiencing a boom in the 1930s and 1940s (del Amo et al. 2008). The fact that vanilla was produced in fallow forests, allowed the regeneration of cultivated plots. However, during the 1960s, vanilla prices dropped substantially and cattle production began to increase in importance (del Amo et al. 2008; Ramírez Melgarejo 2002). In the 1970s and 1980s, there was a surge in coffee production, particularly due to the formation of INMECAFE which subsidized and promoted this important export crop (Velásquez 1995). Moreover, black pepper began to be produced in the 1980s and gradually gained significant importance as an additional source of income since the 1990s (del Amo et al. 2008). Finally, the 1990s are marked by the economic coffee crisis and the elimination of INMECAFE in Zozocolco de Hidalgo, significantly affecting coffee production in the municipality. Research presented in this paper evaluates LULCC dynamics in the past three decades, with special attention to the impacts of the coffee crisis on the landscape of the municipality.

\section{Methods}

Results of LULCC dynamics and the evaluation of potential drivers of change in Zozocolco de Hidalgo are based on remote sensing and geographical information systems (GIS) analyses, statistical modeling and socioeconomic surveys. Secondary data sources such as GIS data (INEGI 2008), census data (INEGI 2008) and agricultural production and price data (AGRICOLACD 2006; SIACON 2007; SIAP 2007; Banco de Mexico 2007) also provided valuable information and important inputs for the statistical models. Due to our direct collaboration with an internationally funded agricultural diversification project (DIPROCAFE) currently underway in Zozocolco de Hidalgo, we were also provided with pertinent data and information on the location, characteristics and production of farmers' parcels (mostly coffee farmers) as well other relevant agricultural socioeconomic data.

Two types of statistical modeling approaches were applied which consider different scales of analyses: (1) a landscape scale approach using binary logistic regression models with spatially explicit land use/ land cover data as well as environmental and socioeconomic variables and (2) a parcel scale approach using a multinomial logit econometric model which integrates spatially explicit land use/ land cover, environmental and socioeconomic data as well as additional agricultural economic data.

\section{Remote sensing analysis}

Land use and land cover in the municipality was assessed for the years of 1973, 1989, 1996, 2003 and 2006 using LANDSAT and SPOT imagery data. One SPOT scene and four LANDSAT scenes were used for the remote sensing analyses: a LANDSAT 1 MSS from April 19, 1973; a LANDSAT 5 TM from October 26, 1989; a LANDSAT 5 TM from February 8, 1996; a LANDSAT 7 ETM + from April 24, 2003 and a SPOT 5 from November 22, 2006. All images were pre-processed and underwent orthorectification and radiometric calibration to reduce atmospheric effects using ERDAS Imagine 8.3.1. Image subsets were then made for the study area according to the limits of the municipality.

Supervised classification using the maximum likelihood algorithm in ERDAS Imagine 8.3.1 was used to generate three main land use/land cover classes for all images: (1) forest/agroforest (tree cover), (2) pasture and (3) agriculture. Water, urban areas and clouds were excluded and masked out equally in all classified images. The masked area amounted to a total of 279.82 ha, around $4 \%$ of the entire study area, and cloud cover totaled 10 ha which was only present in the 1989 image. A set of ground truthing points collected in the field during 2007 were used to create training samples and obtain spectral signatures of forest/agroforest tree cover, pasture and agriculture classes for the 2006 SPOT and 2003 LANDSAT images. These training samples were then applied to produce supervised classifications of the 2006 and 2003 images.

Accuracy assessments using the Kappa-Cohen method were conducted on the 2006 and 2003 
Table 1 Accuracy assessment of 2006 land use/land cover classification showing producer's and user's accuracies and kappa statistic
Table 2 Accuracy assessment of 2003 land use/land cover classification showing producer's and user's accuracies and kappa statistic

\begin{tabular}{llllll}
\hline Classified data & \multicolumn{4}{l}{ Reference point data } & \\
\cline { 2 - 6 } & For/agrofor & Pasture & Agriculture & Total & Producer accuracy (\%) \\
\hline Forest/agroforest & 46 & 11 & 7 & 64 & 82.14 \\
Pasture & 10 & 52 & 11 & 73 & 81.25 \\
Agriculture & 0 & 1 & 22 & 23 & 55.00 \\
Total & 56 & 64 & 40 & 160 & \\
User accuracy (\%) & 71.87 & 71.23 & 95.65 & Overall accuracy (\%): 75.00 \\
& & & & Kappa statistic: 0.61 \\
\hline
\end{tabular}

\begin{tabular}{llllll}
\hline Classified data & \multicolumn{4}{l}{ Reference point data } & \\
\cline { 2 - 6 } & For/agrofor & Pasture & Agriculture & Total & Producer accuracy (\%) \\
\hline Forest/agroforest & 39 & 2 & 2 & 43 & 70.91 \\
Pasture & 10 & 50 & 17 & 77 & 81.97 \\
Agriculture & 6 & 9 & 18 & 33 & 48.64 \\
Total & 55 & 61 & 37 & 153 & \\
User accuracy (\%) & 90.70 & 64.93 & 54.55 & Overall accuracy (\%): 69.93 \\
& & & & Kappa statistic: 0.53 \\
\hline
\end{tabular}

classified images based on 160 ground truthing points corresponding to our three main land cover classes (Fielding and Bell 1997; Jenness and Wynne 2007) (Table 1). Being much closer to the date our groundtruthing points were collected, we obtained a higher overall classification accuracy of $75.0 \%$ and Kappa Statistic of 0.61 for the 2006 classification compared to the 2003 classified image which had an overall classification accuracy of $69.0 \%$ and Kappa Statistic of 0.53 (Table 2). Our overall accuracies are acceptable for remote sensing analysis, especially considering the small size of our analysis area (7000 ha), since smaller classified surface areas tend to have greater misclassification errors than large surface areas classified using multispectral images such as LANDSAT and SPOT (http://rst.gsfc.nasa.gov/Sect 13/Sect13_3.html). Moreover, our overall accuracies are comparable to other remote sensing studies (Ellis and Porter-Bolland 2008; Muñoz-Villers and LópezBlanco 2008; Wyman and Stein 2009).

Tree cover in the municipality, including forest and agroforest tree cover, was accurately determined with a positive predictive power of $72 \%$, while pasture and agriculture land use classes had positive predictive powers of 71 and $96 \%$, respectively. Both Tables 1 and 2 also indicate where misclassification errors are common. Lower accuracies for pasture were due to misclassifications with agricultural classes, and lower accuracies in forest/agroforest tree cover were due to misclassifications with pasture and agriculture, mostly due to groundtruthed reference points of recently cleared parcels for pasture in 2007 . A higher accuracy for agriculture is obtained since maize parcels which also contain bare soil cover are easily distinguished in the imagery. However, maize parcels that are already overgrown with weeds after being cultivated and harvested can be misclassified as pasture.

The 1989 and 1996 LANDSAT images were classified by evaluating mean spectral signature plots of bands 1, 2, 3, 4, 5 and 7 corresponding to the three land use/land cover classes of the 2003 LANDSAT image. Training samples used to classify the 1989 and 1996 images were obtained from locations having matching signature plots with the 2003 image and which were visually similar and unchanged in the 2003 image. For the 1973 image classification, a similar procedure is applied, with the exception that mean signature plots of bands 1, 2, 3 and 4 for each land use/land cover class are evaluated since the LANDSAT MSS image only contains these four sensors. 
Coffee agroforest region mapping

Due to the difficulty and degree of accuracy errors involved in successfully separating agroforest from forest classes in Zozocolco using remote sensing techniques, we decided to keep these classes together in the image classifications and separately determine agroforest regions based on field mapping and GIS techniques. A dataset containing 230 georeferenced production parcels of coffee farmers was obtained from the DIPROCAFE project, totaling almost half the 500 known coffee producers in the municipality. Using GIS procedures, each parcel polygon was converted to a point feature and a point density analysis was applied to calculate the magnitude per unit area of coffee parcels (point features) that fall within the surface of the municipality. With the resulting surface layer indicating point density of coffee parcels, coffee agroforest regions in the municipality were then zoned and mapped based on those areas with the highest density values and occurrence of coffee parcels. ESRI ArcGIS 9.2 and Spatial Analyst were used for GIS procedures described above.

An accuracy assessment was also employed to determine the precision of the derived coffee agroforest regions by combining the mapped agroforest zones with the 2006 classified image and reclassifying the image into four land use/land cover classes: (1) agroforest tree cover, (2) forest or secondary forest tree cover, (3) pasture and (4) agriculture. The same ground truthing points used for the accuracy assessments of the 2003 and 2006 image classifications described above were applied, however, for this assessment, ground truthed coffee agroforest tree cover and forest tree cover reference points were considered separately. An overall accuracy of $68 \%$ and Kappa Statistic of 0.54 was obtained (Table 3).
Additionally, for our mapped agroforest class, a producer accuracy of $85.29 \%$ and user accuracy of $76.32 \%$ was obtained which was considered satisfactory in successfully separating predominantly coffee agroforest tree cover from predominantly natural, secondary and fallow tree cover in the municipality of Zozocolco de Hidalgo (Table 3).

\section{LULCC analysis}

LULCC dynamics in the municipality was assessed by evaluating changes in land use/land cover classes during four periods: (1) 1973-1989, (2) 1989-1996, (3) 1996-2003 and (4) 2003-2006. Rates of change for each land use/land cover class are calculated by applying the formula $\mathrm{dn}=[\mathrm{S} 2 / \mathrm{S} 1]^{1 / n}-1$, a standardized indicator for environmental monitoring in Mexico, where $\mathrm{dn}=$ rate of change, $\mathrm{S} 2=$ land cover in time period two, $\mathrm{S} 1=$ land cover class in time period one and $n=$ number of years between time periods (Palacio-Prieto et al. 2004). If there is a loss of forest or tree cover, for example, a negative rate is obtained, while an increase in tree cover results in positive rate of change. To determine to what extent LULCC or specifically loss of tree cover in Zozocolco de Hidalgo involves the conversion of agroforests to other land uses (pasture or agriculture), we compare deforestation rates within the mapped coffee agroforest regions and outside, corresponding to other forested regions without coffee agroforests.

\section{Logistic regression modeling}

Binary logistic regression modeling is also applied to examine potential environmental and socioeconomic variables or drivers affecting LULCC. For these analyses, all classified land use/land cover images
Table 3 Accuracy assessment of 2003 land use/land cover classification including mapped agroforest zones showing producer's and user's accuracies and kappa statistic

\begin{tabular}{lllllll}
\hline Classified data & \multicolumn{6}{l}{ Reference point data } \\
\cline { 2 - 7 } & Forest & Pasture & Agric. & Agrofor. & Total & Producer accuracy (\%) \\
\hline Forest & 9 & 1 & 4 & 3 & 17 & 42.85 \\
Pasture & 6 & 51 & 12 & 1 & 70 & 79.68 \\
Agriculture & 3 & 10 & 17 & 1 & 31 & 45.94 \\
Agroforest zones & 3 & 2 & 4 & 29 & 38 & 85.29 \\
Total & 21 & 64 & 37 & 34 & 156 & \\
User accuracy (\%) & 52.94 & 72.86 & 54.83 & 76.32 & Overall accuracy (\%): 67.95 \\
& & & & & Kappa statistic: 0.54 \\
\hline
\end{tabular}


were reclassified into two categories: (1) tree cover (forest/agroforest) and (2) deforested (agriculture and pasture), and then combined for each time period (1973-1989, 1989-1996, 1996-2003 and 2003-2006) producing four change-detection images consisting of four categories: (1) tree cover loss, (2) tree cover regeneration, (3) unchanged tree cover and (4) unchanged deforested areas.

We use tree cover loss as the binary response or dependent variable for the logistic regression models derived from reclassifying the combined images, where 1 is assigned to tree cover loss and 0 to the rest of the categories. Four response variables of tree cover loss during 1973-1989, 1989-1996, 1996-2003 and 2003-2006 are produced. Binary logistic regressions are employed to explore patterns and potential drivers of tree cover loss during the four analysis periods. Spatial data used as explanatory or independent variables include (1) elevation, (2) slope, (3) distance to roads, (4) distance to settlements, (5) distance to streams, (6) distance to markets, (7) population density index, (8) settlement marginalization index, (9) distance to existing coffee parcels and (10) presence or absence within agroforest regions. Variables of distance to coffee areas and presence or absence in agroforest regions were included to evaluate the impact of deforestation in relation to agroforest areas in the municipality. Data used to derive spatial explanatory variables included the 2005 municipal census data (INEGI 2008) and GIS vector data (scale of 1:50,000) from the National Institute for Statistics, Geography and Informatics (INEGI 2006), with the exception of distance to coffee parcels which was derived from GPS points of 230 coffee parcels provided by DIPROCAFE. Spatial layers for dependent and explanatory variables in raster format and applied in the binary logistic models were created by applying buffer or kriging procedures using ArcGIS 9.2 Spatial Analyst (ESRI) for GIS processing needs.

For the binary logistic regression modeling we use 120 randomly selected points which were tested for spatial autocorrelation of the response variables. In our final selection of 120 points we obtain no spatial autocorrelation for our four response variables (Moran's Index $=0.02$ and Z score $=1.24$ or better). Cell values corresponding to our response and explanatory variables are extracted for each random point. Logistic regressions were then performed with XLStat2009 using the "Best Model" Logit Model.
Socioeconomic surveys

Part of our field research involved obtaining information through household surveys on socioeconomic and agricultural production characteristics as well as land use history in the municipality. A total of 38 surveys were conducted between September and November 2007 in randomly selected households throughout the municipality. In addition, information on past and present land use and agricultural production characteristics in parcels were obtained through parcel visits of each surveyed household. Interviews with municipal authorities and other key informants were also conducted during field visits. The data and information on agricultural production and past and present land uses obtained from the farmer surveys, parcel visits and interviews provide a valuable complement to the study, particularly in evaluating LULCC dynamics and drivers.

\section{Socioeconometric modeling}

Resource economists have been studying LULCC for decades. The resulting literature has revealed that varying economic conditions can be significant determinants of land cover change (Geist and Lambin 2001, 2002; Lambin et al. 2001). Much of this literature uses discrete choice frameworks to model LULCC decisions (e.g., Munroe et al. 2004; Chomitz and Thomas 2003; Deininger and Minten 2002; Nelson et al. 2001; Cropper et al. 2001; Lambin et al. 2000; Nelson and Hellerstein 1997; Chomitz and Gray 1996). Examples include logit and probit models which estimate the probability of observing each land use as a function of multiple explanatory variables that are thought to influence the desirability of each use from the perspective of the landowner. Assuming landowners are economically rational, then desirability can be equated with profitability, and a landowner would be expected to put his or her land to its most profitable use. This may not always be the case-for example, a landowner may feel a strong conservation ethic and may not select the most profitable use if it entails a large amount of environmental damage; another landowner may have incomplete information about profitability and thus may choose a less profitable use-but, by and large, there is a strong incentive for farmers to use their land 
productively in order to increase personal income and raise their standards of living.

To model this profit-seeking tendency, suppose a farmer must choose one of $J$ discrete actions regarding how to use parcel $i$ during year $t$, and that each choice $j$ produces a payoff $\tilde{v}_{i j t}$. Suppose further that the farmer knows all of the payoffs and chooses the action with the highest payoff. The researcher observes the choice but not the payoffs; however the researcher can observe certain state variables $\mathbf{x}_{i j t}$ that affect the payoffs. Therefore, the researcher treats $\tilde{v}_{i j t}$ as a random variable with expectation $v\left(\mathbf{x}_{i j t}, \beta_{j}\right)$, where $\beta_{j}$ is a parameter vector that accounts for the relative impact of each state variable on the expected payoff for land use $j$. We can then define $\tilde{v}_{i j t} \equiv v\left(\mathbf{x}_{i j t}, \beta_{j}\right)+\varepsilon_{i j t}$, where $\varepsilon_{i j t}$ is a random variable with mean zero. If the $\varepsilon_{i j t}$ are independent and identically distributed Gumbel deviates, then a multinomial logit (MNL) model results with the probability of observing any choice $j$ at parcel $i$ during year $t$ given by: $\pi_{i j t} \equiv e^{v\left(x_{i j t}, \beta_{j}\right)} / \sum_{k} e^{v\left(x_{i k t}, \beta_{k}\right)} \cdot{ }^{1}$ For a given set of parcels, the sample log-likelihood function is given by $L \equiv \sum_{i} \sum_{j} \sum_{t} y_{i j t} \log \left(\pi_{i j t}\right)$, where $y_{i j t}=1$ if parcel $i$ is put to use $j$ during year $t$ and $y_{i j t}=0$ otherwise. Given a dataset of choices $\mathbf{y}$ and state variables $\mathbf{x}$, the researcher's goal is to first specify the function $v\left(\mathbf{x}_{i j t}, \beta_{j}\right)$ and then estimate values for the $\beta_{j}$ that maximize $L$ and, by this measure, best describe the behavior exhibited by the farmers. Note that, because only relative payoff magnitudes affect choices in this framework, one vector $\beta_{j}$ must be set equal to zero to properly identify the estimation problem.

The natural specification for $v\left(\mathbf{x}_{i j t}, \beta_{j}\right)$ is one that mimics the profit function. Given the focus of this study on the effects of output price fluctuations on land use decisions, and the fact that there has been relatively little change in production methods over the past few decades (Raymundo Marcos-Martinez, personal communication, June 2008), we use the following specification for profit: $v_{j t} \equiv p_{j t} y_{j t}-c_{j}$, where $p_{j t}$ is the price per unit of output $j$ during year $t ; y_{j t}$ is the yield per hectare of output $j$ during year $t$; and $c_{j}$ is the cost per hectare of producing output $j$. Furthermore we allow profit to differ across parcels

\footnotetext{
${ }^{1}$ The MNL specification is used frequently because both the sample likelihood function and the welfare effects of changes in relevant variable values have closed-form solutions.
}

based on observable parcel characteristics which we assume affect profit in a linear fashion: $v_{i j t} \equiv v_{j t}+$ $\mathbf{x}_{i j} \beta_{j}$. Therefore, we can define $v\left(\mathbf{x}_{i j t}, \beta_{j}\right) \equiv \mathbf{x}_{i j t} \beta_{j}$, where $\mathbf{x}$ has been expanded to include $v_{j t}$.

For this land parcel scale analysis, we consider four different potential land uses for each parcel derived from the LULCC data described above: agroforestry (coffee and pepper), pasture (cattle), agriculture (corn grain and husks) and fallow, classified as regeneration (15 years or less) in a parcel. For each land use we use several data sources (AGRICOLACD 2006; SIACON 2007; SIAP 2007; Banco de Mexico 2007; others $^{2}$ ) to construct historical estimates of the annual profit from operating one hectare of land. Because landowners typically are not very responsive to short-term fluctuations in profit, largely due to the significant costs associated with changing land uses, we use 5-year averages to describe the relevant profit variable (i.e., $p_{j t} y_{j t} \equiv$ $\left.\sum_{s=t-4}^{t} p_{j s} y_{j s}\right)$. For fallow land we use Mexican nonagricultural GDP per capita as a measure of the potential profit that can be earned from fallowing or abandoning land and working in another sector of the economy. Furthermore, because only relative payoffs affect choices, we use this variable to normalize the agricultural profits and thus we set $\beta_{\text {fallow }}=0$ for identification.

To populate the dataset for this model, we rely heavily on the remote sensing and GIS data described previously. Because we are primarily interested in canopy loss in coffee agroforest regions, we randomly select from the remote sensing data 115 spatially referenced parcels in and around the coffee region of Zozocolco. We then record the land use/ land cover history as well as the state variables (i.e., slope, elevation, soil texture, distance to nearest road and distance to nearest market) for each parcel. In addition to our historical price data, we also append historical population data from INEGI (2006) to control for the land development pressure typically caused by a growing population. Summary statistics for the dataset are provided in Table 4.

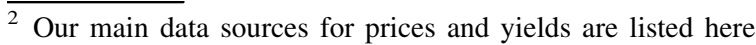
and in the references. Data on costs of production are relatively limited and thus several other sources, including surveys of farmers, were used to estimate these. Additional information is available from the authors upon request.
} 
Table 4 Summary statistics for socioeconomic variables used in parcel based socioeconometric modeling

\begin{tabular}{ll}
\hline Variable & Description $^{\text {a }}$ \\
\hline Agroforestry parcels & Number of agroforestry observations \\
Pasture parcels & Number of pasture observations \\
Agriculture parcels & Number of agriculture observations \\
Fallowed parcels & Number of fallow observations \\
Agroforestry profit & Profit from agroforestry (\$/ha-yr) \\
Pasture profit & Profit from pasture $(\$ /$ ha-yr) \\
Agriculture profit & Profit from agriculture $(\$ /$ ha-yr) \\
Fallow profit (alternate wage) & Mexican non-agricultural GDP per capita $(\$ / y r)$ \\
Population ${ }^{\text {c }}$ & Population of Zozocolco de Hidalgo \\
Slope & Slope of parcel $(\%)$ \\
Elevation & Elevation of parcel (m) \\
Soil texture & Soil texture of parcel $(1=$ fine, $2=$ medium, $3=$ coarse) \\
Distance to road & Distance from parcel to nearest road $(\mathrm{m})$ \\
Distance to market & Distance from parcel to nearest market $(\mathrm{m})$ \\
\hline a Currency units $(\$)$ measured in year-2000 pesos & 11 \\
b Means are calculated across all parcels and/or time periods, where applicable & \\
c Source: INEGI and CONAPO &
\end{tabular}

\section{Results}

\section{LULCC dynamics}

Remote sensing techniques and analysis proved to be a valuable tool and an effective method in assessing LULCC dynamics in the municipality of Zozocolco de Hidalgo. Accuracy assessments were satisfactory, with an overall accuracy of our classified land use/ land cover data of $75 \%$. LULCC analyses revealed spatial and temporal trends and patterns of land use and tree cover in the landscape of Zozocolco. The current landscape of Zozocolco de Hidalgo consists of a mosaic of tree cover (forest/agroforest), pasture and agriculture (Fig. 2). Based on our 2006 image classification, tree cover in the municipality totals 2640 ha (43\%), pasture land use totals 2628 ha (39\%) and land use for agriculture, predominantly maize cultivation, totals 1202 ha (18\%).

Temporal trends in surface area and percentage for the three land use/land cover classes of forest/ agroforest (tree cover), pasture and agriculture are indicated in Fig. 3. In Zozocolco, tree cover remains stable from 1973 to 1989 , declining only slightly from 55 to $53 \%$. However, tree cover increases sharply from 1989 to 1996 up to $61 \%$, and is followed by a sharp decrease in tree cover from 1996 to 2003 to $47 \%$, continuing to decrease in the most recent period of 2003 to 2006 to $43 \%$ (Fig. 3). Trends in land use observed in Zozocolco show a sharp decrease in pasture, 40-26\%, from 1973 to 1996 followed by a sharp increase in pasture, 26-39\%, from 1996 to 2006 (Fig. 3). Land use for agriculture, predominantly for maize cultivation, tends to increase steadily from 1973 to 2006 (5-18\%), although it remains proportionally low in the landscape (18\% in 2006) (Fig. 3).

Table 5 and Fig. 4 show annual rates of change for each land use/land cover class and for each period of analysis (1973-1989, 1989-1996, 19962003, 2003-2006), representing the LULCC trends described above as well as indicating the magnitude of change. Changes in tree cover dynamics for each period are spatially represented in Fig. 5. In Zozocolco, annual rates of change in tree cover show relative stability with only a slight decline $(-0.26)$ between 1973 and 1986. In the following period of 1989-1996, results show a high rate of tree cover regeneration (2.12), mostly occurring in former pasture areas (Table 5; Figs. 4, 5). However, recent losses in tree cover are significantly high with annual rates of -3.89 and -2.07 for the last two analysis periods of 
Fig. 2 2003 Land use/land cover classification and coffee agroforest regions in Zozocolco de Hidalgo

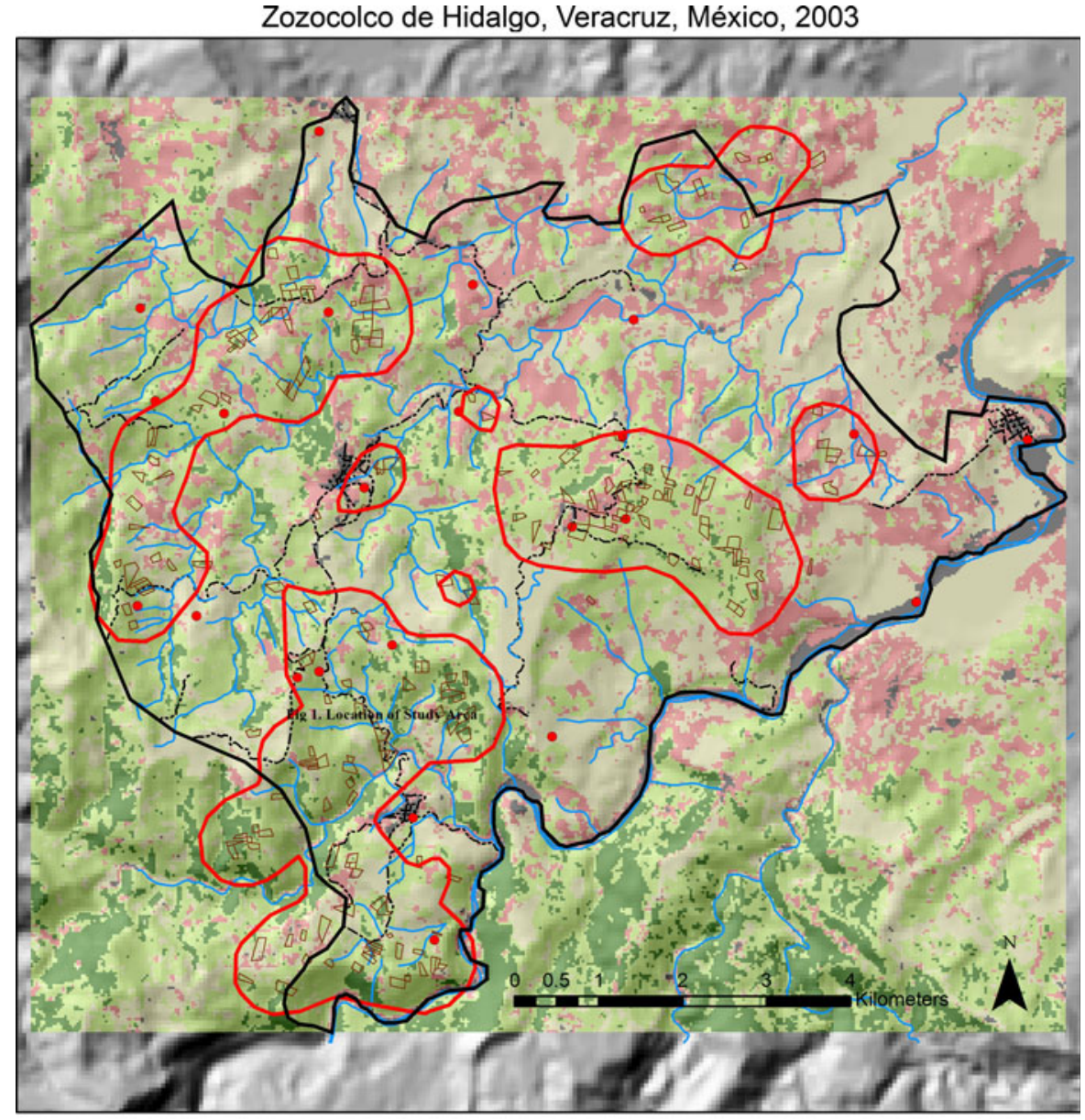

\begin{tabular}{ll|}
\hline Legend \\
Cozocolco Municipal Limit \\
Coffee Parcels \\
Settlements
\end{tabular}

1996-2003 and 2003-2006, respectively (Table 5; Fig. 4). Related to these trends in tree cover loss, agriculture and pasture areas increase very sharply between 1996 and 2003, while only pasture areas increase at a high rate between 2003 and 2006 (Table 5).

Changes in tree cover are also evaluated within and without our mapped coffee agrforest regions (Table 5; Fig. 4). This assessment provides a means to differentiate between tree cover losses that are predominantly associated with the conversion of coffee agroforests from tree cover loss predominantly associated with deforestation in natural, secondary or fallow forests outside mapped coffee agroforest regions. Annual rates of change of tree cover within coffee agroforest regions and outside of them are also spatially represented in Fig. 5. Results for Zozocolco show consistently low rates of tree cover loss within coffee agroforest regions from 1973 to 2003, ranging from -0.32 to -0.47 (Table 5; Fig. 4). However, the rate of tree cover loss within coffee agroforest regions increases substantially to -1.78 from 2003 to 2006 (Table 5; Fig. 4). 

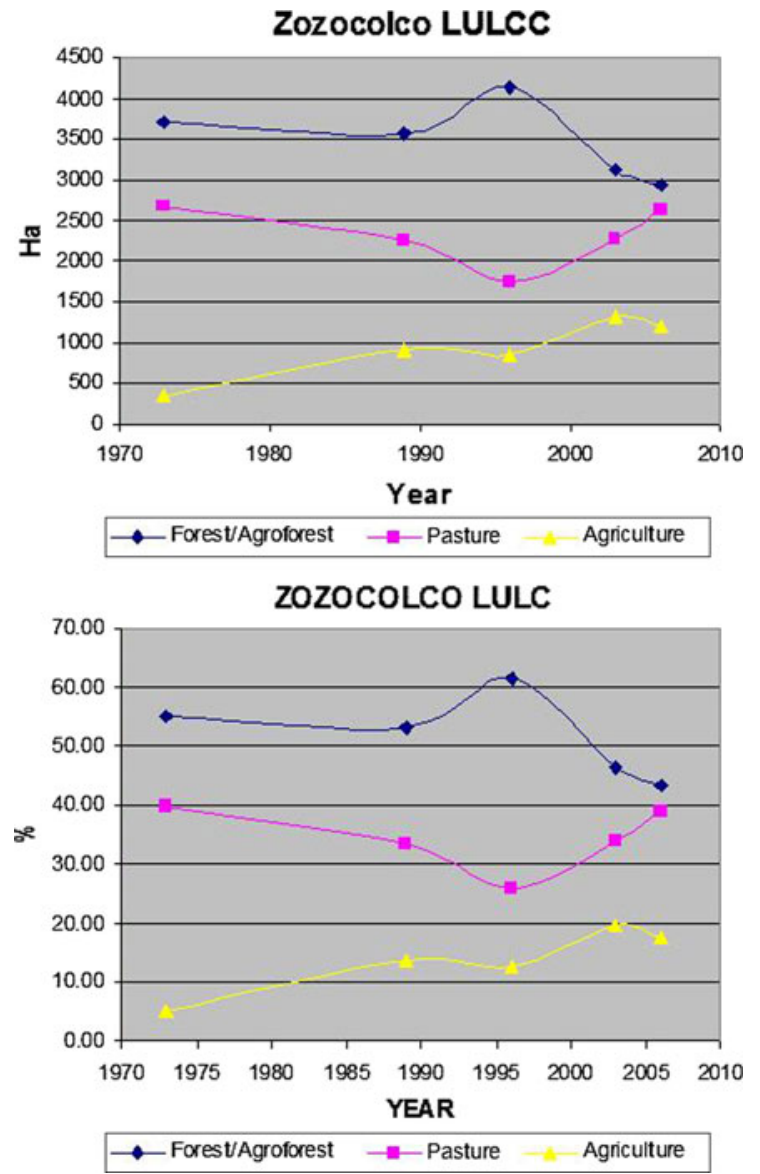

Fig. 3 Land use/land cover surface area (ha) and percent area (\%) from 1973 to 2006 in the municipality of Zozocolco de Hidalgo

A very dynamic trend in tree cover outside of coffee agroforest regions is observed in Zozocolco which reflect the overall trends in the municipality. For example, LULCC results show that the sharp increase in tree cover regeneration in the municipality observed from 1989 to 1996 is associated with the high rate of regeneration outside agroforest regions (Table 5; Figs. 4, 5). This regenerated tree cover consists of young fallow or secondary forests resulting from under utilized or abandoned pasture. Moreover, the drastic loss of tree cover in Zozocolco experienced between 1996 and 2003 is also a result of high rates of tree cover loss outside coffee agroforest regions. Much of this loss of tree cover occurs in the same areas regenerated between 1989 and 1996 (Fig. 5). Between 2003 and 2006, however, tree cover loss has been much lower and even minimal outside agroforest regions compared to within, raising concerns on a current trend of agroforest tree cover loss in the municipality.

Factors driving tree cover loss

Binary logistic regression models performed on the response variables of tree cover loss in Zozocolco for periods 1973-1989, 1989-1996, 1996-2003 and 2003-2006 provided a means to explore related environmental and socioeconomic factors or drivers. Table 6 summarizes overall model statistics of the four -2 Log (likelihood) binary logistic regressions models. All models were statistically significant to the $P<0.1$ level. However, the strongest models, statistically significant to the $P<0.01$ level and with the best goodness of fit (Nagelkerke $R^{2}=0.15$ ), corresponded to the last two periods (1996-2003 and 2003-2006). These two periods in particular were associated with higher annual rates and the sharpest decline of tree cover loss in the municipality. As mentioned above, the annual rate of tree cover loss from 1973 to 1989 was very low $(-0.26)$, and tree cover actually increases from 1989 to 1996 (2.1).

As previously stated, explanatory variables used in the binary logistic regression models in order to evaluate the probability of tree cover loss during each analysis period included: (1) elevation, (2) slope, (3) distance to roads, (4) distance to settlements, (5) distance to streams, (6) distance to markets, (7) population density index, (8) settlement marginalization index, (9) distance to existing coffee parcels and (10) presence or absence within agroforest regions. This set of spatially-explicit explanatory variables represent both environmental and socioeconomic factors commonly associated with LULCC, particularly deforestation. In addition, variables such as distance from coffee parcels and presence or absence within agroforest regions were included to evaluate the probability of tree cover loss associated with agroforest and nonagroforest tree cover.

Tables 6 and 7 show the results of the $-2 \log$ (Likelihood) best models (logit) obtained for the probability of tree cover loss during the four analysis periods. The most influential and significant explanatory variables selected for each model show that environmentally related factors, specifically elevation and slope, were mostly associated with the probability 
Table 5 Annual rates of change for each land use/ land cover class and of tree cover within and outside of coffee agroforest regions in Zozocolco for each period of analysis (1973-1989, 1989-1996, 1996-2003, 2003-2006)

\begin{tabular}{llccc}
\hline Study area/LULCC & \multicolumn{4}{l}{ Analysis period } \\
\cline { 2 - 5 } & $1973-1989$ & $1989-1996$ & $1996-2003$ & 2003-2006 \\
\hline Zozocolco & & & & \\
Forest/agroforest (tree cover) & -0.26 & 2.12 & -3.89 & -2.07 \\
Pasture & -1.13 & -3.56 & 3.87 & 5.05 \\
Agriculture & 6.22 & -0.99 & 6.44 & -3.04 \\
Tree cover loss (coffee region) & -0.32 & -0.47 & -0.41 & -1.78 \\
Tree cover loss (non coffee region) & -0.27 & 3.99 & -6.39 & -0.15 \\
\hline
\end{tabular}
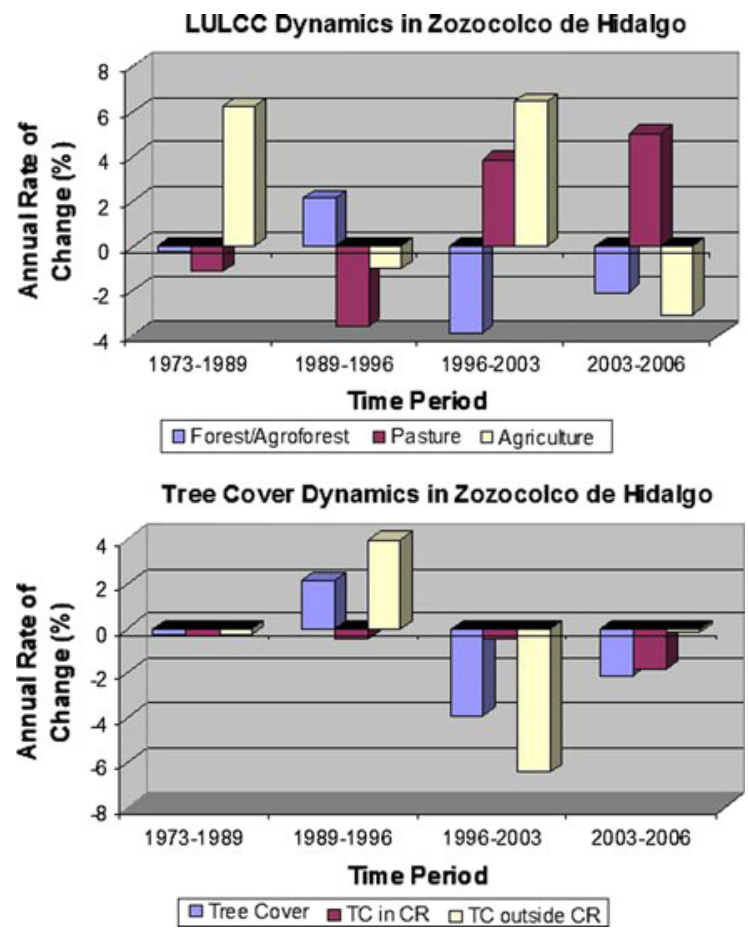

Fig. 4 Annual rate of change in land use/land cover and tree cover within coffee agroforest regions (CR) and outside during the periods of 1973-1989, 1989-1996, 1996-2003 and 2003-2006

of deforestation (Table 7). The strongest models corresponding to tree cover loss in the last two periods (1996-2003 and 2003-2006) demonstrate that decreasing elevation and slope are associated with higher probability of tree cover loss. These models also corroborate LULCC analysis results, indicating a higher probability of tree cover loss from 1996 to 2003 occurring outside of agroforest regions and a higher probability of recent tree cover loss (2003-2006) occurring closer to existing coffee parcels in agroforest regions. This can also be visually observed in Fig. 5 which shows tree cover loss occurring within or bordering agroforest regions, mostly being converted to pasture. Explanatory variables related to socioeconomic factors associated with tree cover loss, such as distance to markets, distance to roads, distance to settlements, population distribution and degree of marginalization (poverty) were not significant or influential in the probability of tree cover loss, with the exception of a slight significance in increasing population during the initial period of 1973-1989.

Socioeconomic survey support

Socioeconomic surveys and interviews in the municipality of Zozocolco contributed valuable socioeconomic, agricultural production and land use history information, providing further support in explaining the observed LULCC dynamics and potential drivers in tree cover loss. Surveys were conducted in 38 randomly selected households stratified according to regions in the municipality which had varying predominant land uses. Each household survey also included visits to their production parcels. In this manner, we were able to obtain a representative sample of different types of households and farming activities throughout the whole municipality.

Our results show that household members involved in agricultural production activities are older adults (mean $=49, \mathrm{SD}=7.3$ ), mostly male head of households. Most of them (63\%) were obtaining labor support from other family members, and around half $(53 \%)$ also hired labor on occasions to work in their parcels. Moreover, the majority of interviewed farmers $(82 \%)$ was not involved in off-farm labor and had not received high school level education (67\%). All 

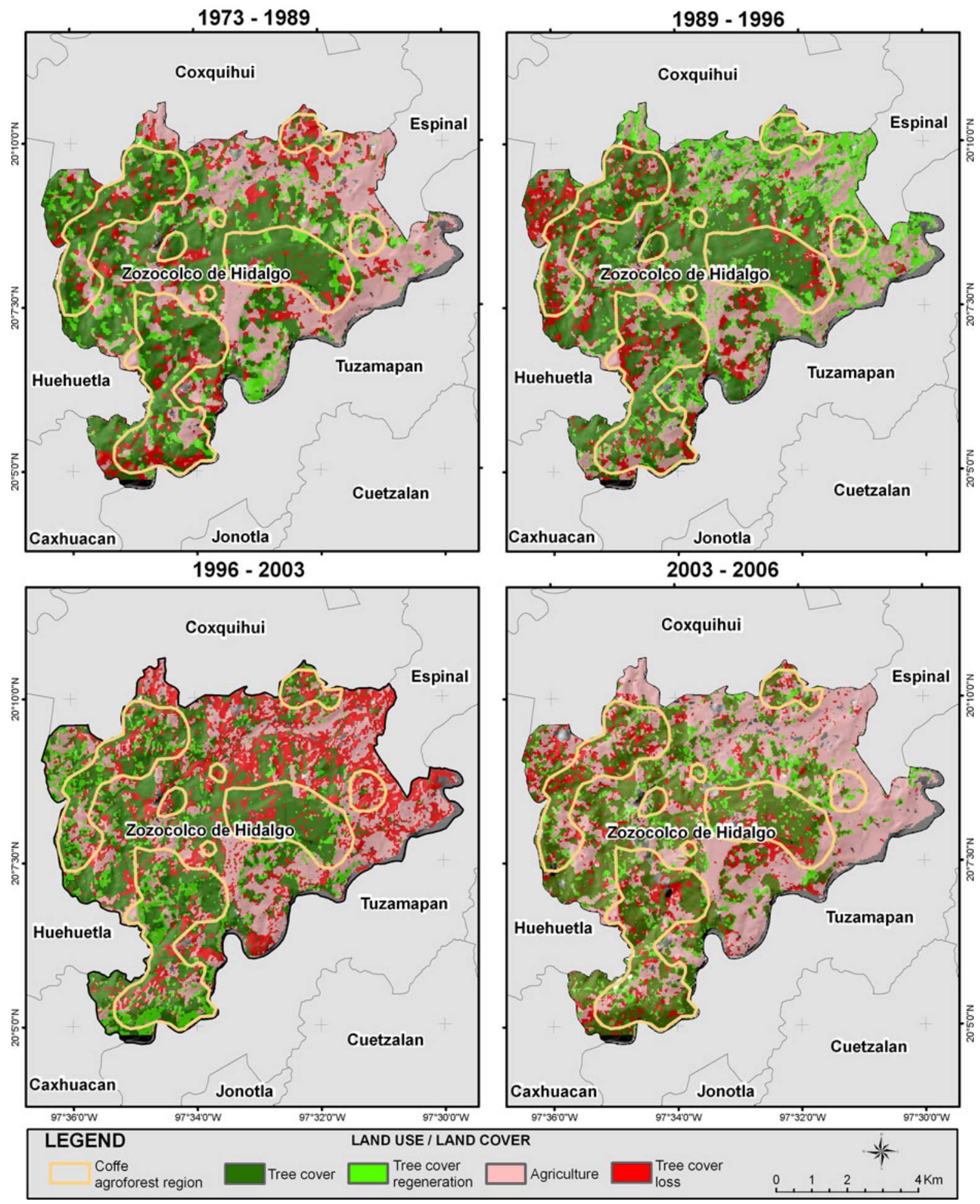

Fig. 5 LULCC dynamics and tree cover loss and regeneration inside and outside of coffee agroforest regions in the municipality of Zozocolco de Hidalgo 
interviewed households owned one land parcel which averaged 1.6 ha in surface area, the mode being 1 ha $(n=15)$ and the maximum land parcel size being 3 ha $(n=1)$. Land tenure of these parcels consisted of $53 \%$ being under the ejido regime and $47 \%$ as private ownership.

Our surveyed sample consisted of 14 households involved in agroforestry activities (36\%), producing coffee $(n=11)$ and black pepper $(n=3) ; 12$ households involved in agricultural activities $(32 \%)$, cultivating maize $(n=11)$ and lemon $(n=1)$; and 12 households with pasture (32\%). Most households $(83 \%)$ were not using inputs of fertilizers and/or pesticides in their parcels. Socioeconomic surveys also show a strong dependence on government or other institutional programs mostly for economic support. Of the surveyed households $71 \%(n=27)$ were receiving such support, the majority (57\%) from a federal government program (Oportunidades) which gives households small monthly payments in return for community services. Only five households (14\%) reported participating in the DIPROCAFE project.

Land use history results revealed that the current reported land uses in parcels averaged a period a 14 years $($ median $=15$ years, minimum $=4$ years, maximum $=25$ years). Sixty percent of surveyed households $(n=23)$ reported current land use in parcels being present between 10 and 15 years, while $24 \%(n=9)$ claimed current land use between 18 and 25 years. Only six households $(16 \%)$ claimed more recent histories of land use which were less than 5 years of age, the majority being maize and pasture, and only two of the surveyed households had recently cultivate coffee. These results also indicate that most land use conversions, particularly for agriculture and pasture, had occurred in the mid 1990s between 1992 and 1996.

Survey results on past land use in production parcels give strong indications of the latest trends in
Table 7 Binary logistic regression -2 Log (Likelihood) best model variables and parameters for the probability of tree cover loss in the municipality of Zozocolco in the periods 1973-1989, 1989-1996, 1996-2003 and 2003-2006

\begin{tabular}{lrlll}
\hline Model variables & $B$ & SE & Wald $\chi^{2}$ & Pr $>\chi^{2}$ \\
\hline Tree cover loss 1973-1989 & & & & \\
Intercept & -1.453 & 1.924 & 0.570 & 0.450 \\
Elevation & -0.006 & 0.003 & 2.838 & 0.092 \\
Population density & 0.001 & 0.001 & 2.963 & 0.085 \\
Tree cover loss 1989-1996 & & & & \\
Intercept & -2.807 & 1.728 & 2.638 & 0.104 \\
Elevation & 0.005 & 0.003 & 4.134 & 0.042 \\
Distance to streams & -0.003 & 0.002 & 1.843 & 0.175 \\
Tree cover loss 1996-2003 & & & & \\
Intercept & 0.524 & 1.353 & 0.150 & 0.698 \\
Elevation & -0.005 & 0.002 & 4.020 & 0.045 \\
Coffee region (outside) & -1.001 & 0.535 & 3.504 & 0.061 \\
Tree cover loss 2003-2006 & & & & \\
Intercept & -0.062 & 1.830 & 0.001 & 0.973 \\
Slope & -0.090 & 0.052 & 2.997 & 0.083 \\
Distance to coffee parcels & -0.003 & 0.001 & 5.304 & 0.021 \\
\hline
\end{tabular}

land use conversion among households in the municipality. The vast majority (92\%) of households with current maize and pasture land uses in their parcels claimed that previous land use was for coffee production or coffee agroforest. Only two of these households reported previous land use as forest. All of the surveyed households with coffee parcels reported previous land use as being the same. In other words, from their perspective, land use in their coffee parcel had always been coffee agroforest. Survey information obtained on future land use or expectations in agricultural production parcels also provide insight on LULCC trends. Around half the housheholds $(53 \%)$ reported that they would keep working and continue current production in their parcels, however, the other half $(46 \%)$ claimed that

Table 6 Binary logistic regression -2 Log (Likelihood) model and goodness of fit statistics for the probability of tree cover loss in Zozocolco in the periods 1973-1989, 1989-1996, 1996-2003 and 2003-2006

\begin{tabular}{llcllll}
\hline Model -2 Log (Likelihood) & DF & -2 Log (Likelihood) & $\operatorname{Pr}>\chi^{2}$ & $R^{2}$ (Nagelkerke) & $R^{2}$ (McFadden) & ROC curve \\
\hline DEF 1973-1989 & 2 & 77.52 & 0.091 & 0.079 & 0.058 & 0.696 \\
DEF 1989-1996 & 2 & 96.06 & 0.068 & 0.077 & 0.053 & 0.658 \\
DEF 1996-2003 & 2 & 126.04 & 0.001 & 0.151 & 0.094 & 0.710 \\
DEF 2003-2006 & 2 & 76.68 & 0.008 & 0.152 & 0.113 & 0.730 \\
\hline
\end{tabular}


they would either sell or rent their parcel. Only 3 of the surveyed households were planning on converting their current land use, two of these were producing coffee and the other maize. Interestingly, among households with pasture, only one had intentions of selling or renting their parcel. However, among those with coffee agroforest land use, over half were considering selling or renting their parcel, and among those with agricultural land parcels a little under half were considering selling or renting their land parcel.

Survey results on current production and land use history in land parcels belonging to local households in the municipality reflect LULCC dynamics derived from the remote sensing analysis. For one, they confirm that most land use conversions and loss of tree cover, primarily for agriculture and pasture have occurred since the mid 1990s. However, survey results show that the majority of land use conversion among parcels has been as a result of coffee agroforest conversion to pasture and agriculture. LULCC results indicate that mostly secondary forest had been converted to pasture between 1996 and 2003. We attribute this discrepancy to the fact, derived from interviews with key informants as well as mentioned in the literature, that the majority of pasture land is owned by only 65 cattle producers, of which only 11 own $60 \%$ of pasture land and do not live in the municipality. It is evident that our surveys did not represent these cattle ranchers due to their small numbers and inaccessibility. Interviews also confirm that cattle production became a major productive activity around 15 years ago a result of government projects and credit support for cattle production.

Survey results show that conversion of coffee agroforests is evident since the mid 1990s. Furthermore, socioeconomic survey and LULCC analysis results indicate that many households with coffee parcels are opting in renting or selling these parcels, which are ultimately converted to pasture land use. It is apparent that agriculture and agroforestry parcels are being sold or rented to cattle producers in the municipality. In that sense, land use in Zozocolco is increasingly being managed and owned by the small percentage of cattle producers, some of which already own large extensions of pasture land (up to $80 \mathrm{ha}$ ) and do not live in the municipality. These findings have strong implications in terms of recent institutional efforts in promoting coffee diversification to conserve agroforest tree cover in the region as well as for conservation and sustainable development strategies in the municipality.

Socioeconometric modeling results

The parcel-level multinomial logit model is estimated in Gauss (Aptech Systems 2003) using the gradientbased Constrained Optimization solver to maximize the likelihood function. The estimated coefficients, standard errors, and significance levels are shown in Table 8. Significance levels notwithstanding, the signs of the estimated coefficients are mostly intuitive. An increase in the 5-year average profit for any land use tended to increase the likelihood of observing that land use. Increased population pressure tended to decrease the likelihood of observing agroforestry and increased the likelihood of observing pasture and agriculture, perhaps reflecting an increased need to provide agricultural products for consumption rather than export and conversion of agriculture to pasture. Agroforestry parcels tended to be found at higher elevations whereas pasture and agriculture are more common at lower elevations. Greater distance to the nearest road, and thus greater transportation cost, decreased the likelihood of observing any active land use (and implicitly increases the likelihood of regeneration or fallowing). However, greater distance to the nearest market increased the likelihood of observing all three active land uses, although this is likely the result of an unobserved correlation or omitted variable in the dataset (e.g., the population variable only captures historical fluctuations at the aggregate level; alternatively, unobserved relationships with intermediaries from more distant markets may be more important than proximity to local markets).

Statistical significance levels for the estimated coefficients generally were low, with only nine of 24 estimates being significant at the $10 \%$ level or better. However, four of the nine significant estimates are agroforestry coefficients, including the coefficient on normalized profit. This is an important result because one of our main concerns is the effect of severe downward fluctuations in the price of coffee on the propensity to clear agroforest for alternative uses. If profitability is an important determinant of land use (i.e., if it is economically significant) then a strong 
Table 8 Coefficient estimates with standard deviations in parenthesis ${ }^{\mathrm{a}}$

\begin{tabular}{llll}
\hline Variable & Agroforestry & Pasture & Agriculture \\
\hline Normalized profit ${ }^{\mathrm{b}}$ & $1.139(0.577) * *$ & $1.853(4.444)$ & $0.611(3.551)$ \\
Population & $-1.569 \mathrm{e}-5(7.551 \mathrm{e}-5)$ & $5.963 \mathrm{e}-6(1.940 \mathrm{e}-5)$ & $1.876 \mathrm{e}-6(1.333 \mathrm{e}-5)$ \\
Slope & $-6.159 \mathrm{e}-3(2.585 \mathrm{e}-2)$ & $7.549 \mathrm{e}-3(2.789 \mathrm{e}-2)$ & $1.078 \mathrm{e}-2(3.057 \mathrm{e}-2)$ \\
Elevation & $6.741 \mathrm{e}-3(1.654 \mathrm{e}-3) * * *$ & $-1.053 \mathrm{e}-3(1.812 \mathrm{e}-3)$ & $-2.911 \mathrm{e}-3(2.007 \mathrm{e}-3) *$ \\
Soil texture & $-0.470(0.346)^{*}$ & $0.257(0.320)$ & $0.286(0.325)$ \\
Distance to road & $-7.015 \mathrm{e}-4(6.165 \mathrm{e}-4)$ & $-1.451 \mathrm{e}-3(6.757 \mathrm{e}-4) * *$ & $-1.283 \mathrm{e}-3(7.667 \mathrm{e}-4) * *$ \\
Distance to market & $2.353 \mathrm{e}-4(1.149 \mathrm{e}-4) * * *$ & $1.995 \mathrm{e}-4(1.232 \mathrm{e}-4) *$ & $2.122 \mathrm{e}-4(1.371 \mathrm{e}-4) *$ \\
Constant & $-8.450 \mathrm{e}-2(1.484)$ & $6.789 \mathrm{e}-2(0.569)$ & $-5.900 \mathrm{e}-3(0.180)$ \\
\hline$*$ Significant at the $10 \%$ level; $* *$ significant at the $5 \%$ level; *** significant at the $1 \%$ level & \\
a Recall that a vector of coefficients is estimated for each land use except fallowing & \\
b Defined as the calculated profit for the specified land use divided by the contemporaneous Mexican non-agricultural GDP per capita
\end{tabular}

argument can be made for the establishment of economic support policies to promote better longterm land stewardship.

Because we have estimated a nonlinear regression model, the economic significance of a change in the relative profitability of agroforestry cannot be judged simply by inspecting the magnitude of the coefficient estimate. However, we can use the estimated regression model to simulate the land use decisions that we would expect to observe given a hypothetical alternative profitability, and thus clarify the economic relevance of this variable. Here we consider two policies that might be used to increase the profitability of agroforestry: (1) a subsidy that increased the price received by shade coffee growers by $50 \%$ relative to the prevailing market price of coffee; (2) a price floor that guaranteed a minimum price received by shade coffee growers, which was set equal to the average price of coffee in our dataset between 1980 and 2006 (\$2747/ton, in year-2000 pesos).

Although these are arguably generous policies, neither had much effect on the amount of land we expect to observe in agroforestry. As Table 9 shows, policy 1 increased the average number of agroforestry parcels from 66 to 69 and policy 2 increased it from 66 to 68 . These policy-induced changes in land use are quite small in both absolute and percentage terms. Even during the period of relatively low prices in the 1990s, neither policy had a substantial effect on land use: policy 1 had the larger effect, increasing the number of agroforestry parcels in 1996 from 63 to 67, which amounted to only a $6.3 \%$ change in the amount of agroforestry. Based on these results, it appears that profitability was not one of the more economically significant determinants of land use in Zozocolco de Hidalgo.

\section{Discussion}

Our research demonstrated LULCC dynamics and evaluated drivers associated with LULCC and tree cover loss in Zozocolco de Hidalgo, a low grade and marginal coffee growing region in the state of Veracruz which is characterized by its indigenous population and poor socioeconomic conditions. These
Table 9 Predicted effects of coffee price support policies on the amount of land in agroforestry parcels

\begin{tabular}{|c|c|c|c|c|c|c|}
\hline \multirow[t]{2}{*}{ Year } & \multicolumn{2}{|l|}{ Observed } & \multicolumn{2}{|l|}{ Policy 1} & \multicolumn{2}{|l|}{ Policy 2} \\
\hline & Percentage & \# of parcels & Percentage & \# of parcels & Percentage & \# of parcels \\
\hline 1989 & 59.5 & 69 & 64.4 & 74 & 59.5 & 68 \\
\hline 1996 & 55.5 & 63 & 58.0 & 67 & 57.1 & 66 \\
\hline 2003 & 58.7 & 66 & 60.3 & 69 & 61.0 & 70 \\
\hline Average & 57.9 & 66 & 60.1 & 69 & 59.2 & 68 \\
\hline
\end{tabular}


results provide valuable and discerning information on land use trends and the conversion of coffee agroforests in the region, particularly relating to the coffee crisis. Moreover, the results presented have major implications regarding sustainable development and conservation initiatives in lowland marginal coffee growing regions in Veracruz, such as coffee agroforest diversification and conservation strategies (e.g., DIPROCAFE).

LULCC results for the municipality show low annual rates of tree cover loss, both in agroforest and non-agroforest regions, between 1973 and 1989 before the coffee crisis. In the following period between 1989 and 1996, coinciding with the beginning of the coffee crisis, tree cover recovers substantially and at a high annual rate outside coffee regions, although continues to decline slightly in coffee agroforest regions. Most households in Zozocolco involved in coffee production tended to conserve their agroforest parcels during this period despite the drastic decline of coffee prices. Other LULCC studies in the state of Veracruz also show that shade coffee plantations were mostly preserved in the following decade after the coffee crisis (Martínez et al. 2009; Tucker et al. 2009; Muñoz-Villers and López-Blanco 2008; Mestries Benquet 2003). Household surveys and interviews conducted in the municipality confirm this trend, indicating that many coffee farmers opted in not converting their agroforest parcel until the mid 1990s with the expectation of more favorable prices. Moreover, the period of 1989-1996 also coincides with a crisis in cattle production in Mexico (Chauvet 1997). This crisis in cattle production is also reflected in our LULCC results which show that the majority of tree cover regeneration during 1989-1996 occurred in areas which had previously been under pasture and pasture land use declines drastically.

In contrast to the previous period, from 1996 to 2003, high annual rates of tree cover loss are observed in Zozocolco. This tree cover loss is mostly associated outside coffee agroforest regions, mainly due to increasing land use for pasture and agriculture and mostly occurring in the same areas that had regenerated from 1989 to 1996. Tree cover loss within agroforest regions also increases slightly compared to previous periods. Survey and interview results also confirm increasing land use in pasture in the municipality since 1995, mainly due to increased government programs and credit support for cattle production.
More recent trends in LULCC (2003-2006), however, indicate a high rate of conversion of coffee agroforests, mostly to pasture. Socioeconomic surveys and interviews in the municipality also support this trend showing that many current agricultural and pasture land parcels had previously been under coffee agroforest land use. Increasing land use in agriculture is reported for the past 25 years, and in the past decade, maize cultivation for corn husks has gained economic importance in the region (King 2007). Furthermore, surveys reveal that many households are opting in renting or selling their production parcels which for the most part are being destined as pasture land use and utilized by the small number of cattle producers in the municipality who own and manage the majority of pasture land. In addition, these households often end up working as caretakers of the cattle on their rented or sold land parcel.

The recent conversion of coffee agroforests to pasture and the appropriation of land by a small segment of cattle producers raises concern regarding the environmental sustainability and social equity in the municipality as well as the efforts of coffee agroforest diversification and conservation strategies promoted by the DIPROCAFE project. Coffee farmers in Zozocolco, predominantly indigenous and with poorer socioeconomic conditions, are preferring to obtain short term returns in income from renting or selling their land parcels rather than investing in long term product diversification efforts in their coffee agroforests. Under the terms proposed by the DIPROCAFE project, household interested in entering the diversification program must also agree to partial loans for investment which may also discourage this option considering their poor economic status.

Logistic regression and econometric modeling results also raise important issues with respect to the factors or drivers behind the observed LULCC in the municipality, particularly in relation to the coffee crisis and coffee agroforest diversification strategies in the region. These models indicate that environmental drivers such as slope and elevation are strong indicators of the occurrence of land use and tree cover loss. Mainly, that areas lower in elevation and slope are more prone to tree cover loss and the occurrence of agriculture and pasture land uses. Increased population pressure is also related to the occurrence of agriculture and pasture, and during 
1973-1989, population pressure was significantly related to tree cover loss. Logistic regression models confirm observed deforestation patterns in the municipality. Principally, from 1996 to 2003, tree cover loss is mostly associated with the conversion of secondary or fallow forest to pasture outside agroforest regions but from 2003 to 2006 tree cover loss is mostly associated with the conversion of coffee agroforests to pasture. Socioeconomic variables such as distance to markets and roads did not have any relationship to tree cover loss and conversion of coffee agroforests in Zozocolco, likely due to being a very remote municipality which is already disconnected to the major market centers and strongly dependent of intermediaries. The econometric model also shows this poor relationship between land use and distance to major markets.

Econometric analyses of land cover in coffee agroecosystems in the state of Oaxaca and El Salvador show relationships between loss of tree cover with areas lower in elevation and slope and at greater distances from major market centers in larger cities (Blackman et al. 2008a, b). Conversely, the study in Oaxaca reports strong relationships between the conservation of coffee agroforests and nearness to these major markets as well as membership in farming cooperatives (Blackman et al. 2008a). It is important to note that the above-mentioned study area in Oaxaca occupies 634,000 ha with an altitudinal range of 400-1600 m and only uses 1993 land use/land cover data. In that sense, our study, provides additional and more specific LULCC information regarding remote, socioeconomically marginalized, and low-grade coffee growing regions in Mexico. Specifically, in Zozocolco, coffee agroforests have mostly been conserved (or abandoned) following the coffee crisis, but more recently (in the last decade), these agroforests are being converted to other land uses. Being a region which is economically "disconnected" and strongly dependent on intermediaries and outside government support, socioeconomic variables such as distance to roads and markets and profitability of land use have little influence on land use changes and tree cover loss in the municipality.

Among the key results of the econometric analysis of this study is the weak relationship or response in LULCC related to prices and profitability, especially with respect to coffee. The multinomial logit model indicates that farmers have been largely unresponsive in converting agroforest land uses to other agricultural land uses despite unfavorable prices. Moreover, even when hypothetical price support subsidies or price floor policies are implemented, these do little to increase the number of agroforest parcels in the model. Ávalos-Sartorio and Blackman (2009) also report similar results from an econometric analysis for the study area in Oaxaca mentioned above. In their analysis, Ávalos-Sartorio and Blackman (2009) find that a current voluntary price support program would only attract a small number of coffee growers mostlikely to deforest and would not target those areas hardest hit by agroforest conversion. Relatedly, Ponette-González (2007) found that poor indigenous coffee farmers in the state of San Luís Potosí tended to conserve and grow coffee well after the 1989 coffee crisis up to 2001 when the study was conducted, even though coffee was not a viable cash-generating strategy for these households. Furthermore, PonetteGonzález (2007) asserts that a purely economic approach does not suffice in explaining why these indigenous households continued to cultivate coffee and adds that household production choices and livelihood strategies must be viewed within a cultural context. We feel that the same issues pertain to Zozocolco de Hidalgo.

In this study, the marginalized population of Zozocolco has responded to the sharp decline in the coffee price largely by maintaining agroforests, either through temporary abandonment of coffee parcels or by augmenting parcels with pepper (allspice), and relying to a greater extent on subsistence farming. Our estimation and simulation results show that government programs like DIPROCAFE are not likely to be too successful in terms of ecological goals or agroforest tree cover preservation in poor and marginal municipalities such as Zozocolco. However, direct income assistance programs would do more to reduce inequality and perhaps deforestation in regions like Zozocolco. Programs like DIPROCAFE appear useful and appropriate for preventing deforestation. However, they certainly are not the only option for reducing inequality, and apparently are not very efficient in reducing agroforest tree cover loss considering recent trends. Governments must be careful when extrapolating results of pilot studies for programs such as DIPROCAFE. Pre-planning, with similar research as the one presented, should be conducted to formulate more case-specific strategies 
for agroforest conservation and income improvement in lowland, low-grade coffee growing regions. Moreover, information about locally varying cultural contexts needs to be strongly considered in order to formulate effective strategies in marginal coffee growing regions such as Zozocolco.

Acknowledgments This material is based upon work supported by a grant from the University of California Institute for México and the United States (UC-MEXUS) and the Consejo Nacional de Ciencia y Tecnología de México (CONACYT). We are grateful to Irving Uriel Hernández Gómez and César Gallo Gómez for their support with GIS processing and field work, Marisol Martínez Bello for her support with remote sensing and Emma Cesta Arrieta for her support conducting surveys and interviews. We would also like to thank the municipal authorities and farmers of Zozocolco de Hidalgo and the DIPROCAFE project.

Open Access This article is distributed under the terms of the Creative Commons Attribution Noncommercial License which permits any noncommercial use, distribution, and reproduction in any medium, provided the original author(s) and source are credited.

\section{References}

Angelsen A, Kaiminowitz D (2004) Is agroforestry likely to reduce deforestation? In: Schroth G, da Fonseca GAB, Harvey CA, Gascon C, Vasconcelos HL, Izac AN (eds) Agroforestry and biodiversity conservation in tropical landscapes. Island Press, Washington, DC

Anuario Agropecuario (AGRICOLACD) (2006) http://www. oeidrus-tamaulipas.gob.mx/cd_anuario_06/AGRICOLACD_ 2006_A.html

Ávalos-Sartorio B, Blackman A (2009) Agroforestry price supports as a conservation tool: Mexican shade coffee. Agroforest Syst. doi:10.1007/s10457-009-9242-4

Banco de Mexico (2007) Indice Nacional de Precios al Consumidor Agropecuarios. http://www.banxico.gob.mx/Sie Internet/consultarDirectorioInternetAction.do?accion $=$ con sultarCuadroAnalitico \&idCuadro $=\mathrm{CA} 55 \&$ sector $=8 \& 1$ loc ale $=$ es

Banco Nacional de Comercio Exterior (BANCO-MEXT) (2005) Exportaciones e Importaciones en México. Méxi$\mathrm{co}, \mathrm{DF}$

Blackman A, Ávalos-Sartorio B, Chow J (2007) Tree cover loss in El Salvador's shade coffee areas. RFF DP 07-32. Resources for the Future, Washington, DC

Blackman A, Albers HJ, Ávalos-Sartorio B, Murphy LC (2008a) Land cover in a managed forest ecosystem: Mexican shade coffee. Am J Agric Econ 90:216-231

Blackman A, Ávalos-Sartorio B, Chow J (2008b) Land cover change in mixed agroforeestry. EfD DP 08-25. Environment for Development/Resources for the Future, Washington, DC

Blanco RJL (1987) Territorio y política. In: Urias M (coord.) Coxquihui, Chumatlán y Zozocolco de Hidalgo: Tres
Municipios del Estado de Veracruz. Historia y realidad actual: 1821-1987. Coordinadora Estatal de Veracruz. Instituto Nacional Indigenista. Xalapa, Veracruz. México. 2006. Consejo Nacional de Población 2006. Secretaría Gobernación. http://www.conapo.gob.mx

Chauvet M (1997) La ganadería Mexicana al frente de siglo. Prepared for the delivery at the 1997 meeting of the Latin American Studies Association, 17-19 April. Guadalajara, México

Chomitz K, Gray DA (1996) Roads, land use, and deforestation: a spatial model applied to Belize. World Bank Econ Rev 10:487-512

Chomitz K, Thomas T (2003) Determinants of land use in Amazonia: a fine-scale spatial analysis. Am J Agric Econ 85:1016-1028

Comisión Veracruzana de Comercialización Agropecuaria (COVECA) (2002) Estudio de Reconversión Zonas Productoras de Café. Servicios Profesionales Integrales para el Desarrollo Regional. Xalapa, Veracruz

Consejo Nacional de Población (CONAPO) (2009) Indices de marginación 2005. Mexico, DF. http://www.conapo.gob.mx

Cropper M, Puri J, Griffiths C (2001) Predicting the location of deforestation: the role of roads and protected areas in north Thailand. Land Econ 77:172-186

Deininger K, Minten B (2002) Determinants of deforestation and the economics of protection: an application to Mexico. Am J Agric Econ 84:943-960

del Amo SR, Vergara Tenorio C, Ramos Prado JM, Jiménez Valdéz ML, Ellis EA (2008) Plan de Ordenamiento Ecológico de Participación Comunitaria del Municipio Zozocolco de Hidalgo, Veracruz. Universidad Veracruzana, Xalapa, Veracruz

Del Angel-Pérez AD, Mendoza MA (2004) Totonac homegardens and natural resources in Veracruz, Mexico. Agric Hum Values 21:329-346

Ellis EA, Porter-Bolland L (2008) Is community-based forest management more effective than protected areas? A comparison of land use/land cover change in two neighboring study areas of the Central Yucatan Peninsula, Mexico. For Ecol Manag 256:1971-1983

Ellis EA, Martínez-Bello M, Monroy-Ibarra R (2010) Focos rojos para la conservación de la biodiversidad. In: La biodiversidad en Veracruz: Estudio de estado. CONABIO, Mexico, DF

Fielding AH, Bell JF (1997) A review of methods for the assessment of prediction errors in conservation presence/ absence models. Environ Conserv 24(1):38-49

Food and Agriculture Organization (FAO) (2006) Global forest resources assessment 2005: progress towards sustainable forest management. FAO Forestry Paper 147. Food and Agriculture Organization of the United Nations, Rome, Italy

García E (1988) Modificacciones al Sistema de Clasificación Climática de Koppen, 4th edn. México, DF

Geist HJ, Lambin EF (2001) What drives tropical deforestation? A meta analysis of proximate and underlying causes of deforestation based on subnational case study evidence. LUCC Report Series No. 4. University of Louvain, Louvain-la-Nueve

Geist HJ, Lambin EF (2002) Proximate causes and underlying driving forces of tropical deforestation. Bioscience 52: 143-150 
Gordon CR, Manson R, Sundberg J, Cruz-Angón A (2007) Biodiversity, profitability, and vegetation structure in a Mexican coffee agroecosystem. Agric Ecosyst Environ 118:256-266

Instituto Nacional de Estadística, Geografía e Informática (INEGI) (2006) Conjunto de Datos Topográficos Vectoriales. Aguascalientes, México

Instituto Nacional de Estadística, Geografía e Informática (INEGI) (2008) II Conteo de Población y Vivienda 2005: Veracruz Ignacion de la Llave. Aguascalientes, México

International Coffee Organization (ICO) (2005) Historical data. London. http://dev.ico.org/prices/po.htm

International Coffee Organization (ICO) (2009) Historical data. London. http://dev.ico.org/prices/po.htm

Jenness J, Wynne JJ (2007). Cohen's kappa and classification table metrics 2.1: An arcview 3x extension for accuracy assessment of spatially explicit models. http://www.jesse ssent.com/arcview/kappa_stats.htm

King A (2007) Trade and totomoxtle: livelihood strategies in the Totonacan region of Veracruz, Mexico. Agric Hum Values 24:29-40

Lambin EF, Rounsevell MDA, Geist HJ (2000) Are agricultural land use models able to predict changes in land-use intensity? Agric Ecosyst Environ 82:321-331

Lambin EF, Turner BL, Geist HJ, Agbola SB, Angelsen A, Bruce JW, Coomes OT, Dirzo R, Fischer G, Folke C, George PS, Homewood K, Imbernon J, Leemans R, Li X, Moran EF, Mortimore M, Ramakrishnan PS, Richards JF, Skanes H, Steffen W, Stone GD, Svedin U, Veldkamp TA, Vogel C, Xu J (2001) The causes of land-use and land-cover change: moving beyond myths. Glob Environ Change 11:261-269

Martínez ML, Pérez-Maqueo O, Vázquez G, Castillo-Campos G, García-Franco J, Mehltreter K, Equihua M, Landgrave R (2009) Effects of land use change on biodiversity and ecosystem services in tropical montane cloud forest of Mexico. For Ecol Manag 258:1856-1863

Mestries Benquet F (2003) Crisis cafetalera y migración internacional en Veracruz. Migraciones Internacionales 2(2):121-148

Muñoz-Villers LE, López-Blanco J (2008) Land use/cover changes using Landsat TM/ETM images in a tropical biodiverse mountainous area of central-eastern Mexico. Int J Remote Sens 29(1):71-93

Munroe D, Southworth J, Tucker C (2004) Modeling spatially and temporally complex land-cover change: the case of western Honduras. Prof Geogr 56:544-559

Nelson GC, Hellerstein D (1997) Do roads cause deforestation? Using satellite images in econometric analysis of land use. Am J Agric Econ 79:80-88

Nelson G, Harris V, Stone S (2001) Deforestation, land use and property rights: empirical evidence from Darien, Panama. Land Econ 77:187-205

Overmars KP, Verburg PH (2005) Analysis of land use drivers at the watershed and household level: linking two paradigms at the Phillipine forest fringe. Int J Geogr Inf Sci 19:125-152

Overmars KP, Verburg PH (2006) Multilevel modeling of land use from field to village level in the Phillipines. Agric Syst 89:435-456
Palacio-Prieto JL, Sánchez-Salazar MT, Casado Izquierdo JM, Propin Frejomil E, Delgado Campos J, Velásquez Montes A, Chias Becerril L, Ortíz Álvarez ML, González Sánchez J, Negrete Fernández G, Morales GJ, Márquez Huitzil R (2004) Indicadores para la caracterización y ordenamiento del territorio. SEMARNAT-INE-UNAM, Mexico, DF

Pearce D, Mourato S (2004) The economic valuation of agroforestry's environmental services. In: Schroth G, da Fonseca GAB, Harvey CA, Gascon C, Vasconcelos HL, Izac AN (eds) Agroforestry and biodiversity conservation in tropical landscapes. Island Press, Washington, DC

Ponette-González A (2007) 2001: a household analysis of huasted maya agriculture and land use at the height of the coffee crisis. Hum Ecol 35:289-301

Ramírez Melgarejo R (2002) Política del Estado Mexicano el los Procesos Agrícolas y Agrarios de los Totonacos. Universidad Veracruzana, Xalapa, Veracruz, México

Rindfuss RR, Walsh SJ, Turner BL, Fox J, Mishra V (2004) Developing a science of land change: challenges and methodological issues. PNAS 101(39):13976-13981

Romero Leon K, Houston JH, Epperson JE (2006) Diversification in low-grade coffee- growing areas of Veracruz, Mexico: market possibilities. J Food Distrib Res 37: 143-148

Roy Chowdhury R, Schneider LC (2004) Land cover and land use: classification and change analysis. In: Turner BL, Geoghegan J, Foster D (eds) Integrated land-change science and tropical deforestation in the southern Yucatan: final frontiers. Oxford UP, Oxford, UK

Schroth G, da Fonseca GAB, Harvey CA, Vasconcelos HL, Gascon C, Izac AN (2004) Introduction: the role of agroforestry in biodiversity conservation in tropical landscapes. In: Schroth G, da Fonseca GAB, Harvey CA, Gascon C, Vasconcelos HL, Izac AN (eds) Agroforestry and biodiversity conservation in tropical landscapes. Island Press, Washington, DC

Secretaría del Medio Ambiente y Recursos Naturales (SEMARNAT) (2005) Informe de la situación del medio ambiente en México; compendio de estadísticas ambientales. SEMARNAT y PNUD (Programa de las Naciones Unidas para el Desarrollo). México, DF

Sistema de Informacion Agroalimentaria y Pesquera (SIAP) (2007) http://sqm.siap.gob.mx/viocs/acceso.php

Sistema de Información Agropecuaria de Consulta (SIACON) (2007) http://www.oeidrus-tamaulipas.gob.mx/cd_anuario _06/SIACON_2007.html

Somarriba E, Harvey CA, Samper M, Anthony F, González J, Straver C, Rice RA (2004) Biodiversity conservation in neotropical coffee (Coffea arabica) plantations. In: Schroth G, da Fonseca GAB, Harvey CA, Gascon C, Vasconcelos HL, Izac AN (eds) Agroforestry and biodiversity conservation in tropical landscapes. Island Press, Washington, DC

Tucker CM, Eakin H, Castellanos EJ (2009) Perceptions of risk and adaptation: coffee producers, market shocks, and extreme weather in Central America and Mexico. Glob Environ Change. doi:10.1016/j.gloenvcha.2009.07.006

Vázquez García V (2001) Coffee production and household dynamics: the popolucas of Ocotal Grande, Veracruz. Agric Hum Values 18:57-70 
Velásquez HE (1995) Cuando los arrieros perdieron sus caminos: La conformación regional del Totonacapan. Colegio de Michoacán. Zamora, Michoacán. México

Verburg PH, Schot PP, Dijst MJ, Veldkamp A (2004) Land use change modeling: current practice and research priorities. GeoJournal 61:309-324
Wyman MS, Stein TV (2009) Modeling social and land-use/ land-cover change data to assess drivers of smallholder deforestation in Belize. Appl Geogr. doi:10.1016/japgeog. 2009.10.001 